\title{
Tapinothrix clintonii sp. nov. (Pseudanabaenaceae, Cyanobacteria), a new species at the nexus of five genera
}

\author{
Markéta BoHUnickÁ ${ }^{1}$ Jeffrey R. JoHANSEN², and Karolina FuČíKOVÁ ${ }^{3}$ \\ ${ }^{1}$ Faculty of Science, University of South Bohemia, Branišovská 31, České Budějovice, CZ-370 05, Czech Republic; \\ e-mail: mkrautova09@jcu.edu \\ ${ }^{2}$ Department of Biology, John Carroll University, University Heights, OH 44118, U.S.A. \\ ${ }^{3}$ University of Connecticut, Department of Ecology and Evolutionary Biology, 75 North Eagleville Road, Storrs, \\ CT 06269-3043, U.S.A.
}

\begin{abstract}
A new species was isolated and characterized from Grand Staircase-Escalante National Monument. This taxon shares morphological characteristics with five different genera, Ammatoidea, Homoeothrix, Leptolyngbya, Phormidiochaete, and Tapinothrix. An argument could be made to place it in any of these genera, however, we consider the most taxonomically correct genus for our pseudanabaenalean species to be Tapinothrix, and we accordingly describe it as T. clintonii sp. nov. Phylogenetically, the taxon is closest to Leptolyngbya sensu stricto, but it has very distinctive morphology and 16S-23S ITS sequence and secondary structure that support our conclusion to recognize Tapinothrix as a genus separate from Leptolyngbya.
\end{abstract}

Key words: Ammatoidea, Homoeothrix, Leptolyngbya, Phormidiochaete, Tapinothrix, Cyanobacteria, taxonomy, 16S rRNA, 16S-23S ITS, rRNA secondary structure

\section{Introduction}

In the course of study of the algal flora of Grand Staircase-Escalante National Monument (KRAUTOVÁ 2008), we isolated a distinctive nonheterocytous, filamentous strain of cyanobacteria. This strain is characterized by having isopolar filaments which taper at the apices and fragment in the center to form heteropolar tapering trichomes. The resulting "basal" portion of the heteropolar filament forms a mucilage pad, which likely serves to cement the widened trichome end to the substrate. The cell contents are rich in phycoerythrin, giving the trichomes a reddish coloration, with mature sheaths blackish. Cell organization (thylakoid arrangement and mode of cell division) is typical of the Pseudanabaenaceae.

Within the Pseudanabaenaceae there is a single genus with tapering trichomes whose species are attached to the substrate at the base - Tapinothix Sauvageau. Only two species were described in this genus, T. bornetii Sauvageau (1892) and T. mucicola Borge (1923). Another tapering genus, Homoeothrix (THURET ex BORNET et Flahault) Kirchner (1898) was subsequently described, and many species were described within this taxon (KOMÁREK \& ANAGNOSTIDIS
2005). Tapinothrix bornetii was transferred into Homoeothrix bornetii (Sauvageau) Mabille (1954), and Tapinothrix was forgotten for nearly half a century. In the most recent treatment of the Oscillatoriales, KOMÁReK \& ANAGNOSTIDIS (2005) recognized that Homoeothrix was likely polyphyletic, with the type species, $H$. juliana (BORNET et Flahault) KirChNER clearly belonging to the Oscillatoriaceae, while the majority of described taxa apparently belong in the Pseudanabaenaceae. They concluded that these pseudanabaenacean species belong in Tapinothrix, but they did not make any taxonomic transfers.

In looking for species conforming morphologically to our isolate, the closest species is actually Phormidiochaete fusca (StARMACH) KoMÁrek in Anagnostidis (2001). Phormidiochaete was split out of Homoeothrix to accommodate the species within Homoeothrix that have a mode of cell division and thylakoid structure consistent with the Phormidiaceae (ANAgnostidis 2001). The type species of Phormidiochaete, P. nordstedtii (Bornet et Flahault) Komárek et Anagnostidis, clearly fits into the Phormidiaceae, as does $P$. balearica (Bornet et Flahault) Komárek et AnAGNOSTIDIS. This genus is in the subfamily Ammatoideoideae. However, P. fusca has much smaller diameter than the vast majority of 
Phormidiaceae, and it may have been mistakenly placed in this genus. Interestingly, a feature of our taxon which separates it from Phormidiochaete is the common occurrence of isopolar trichomes tapering towards both apices that bend acutely in the center. Such isopolar forms are placed in the genus Ammatoidea West et G.S. West (1897), which includes mostly species with typical phormidiacean features as well as the apparently pseudanabaenacean marine species $A$. murmanica Petrov (1961).

Finally, we must mention the genus Leptolyngbya. This genus has become the home for a plethora of pseudanabaenacean species transferred from Lyngbya, Plectonema, and Phormidium because of their narrow, untapered trichomes forming simple sheaths. This genus has been said to be a polyphyletic assemblage (Albertano \& KováčIK 1994; Turner 1997; Wilmotte et al. 1997; CAstenholz 2001; Wilmotte \& Herdman 2001; Taton et al. 2003; CASAmatta et al. 2005; KomáreK \& Anagnostidis 2005; JOHANSEN et al. 2008), but no revisionary work recognizing the separate clades as separate genera has been completed.

Our isolate is at the nexus of these five genera. It fits no described species in any genus, and some justification could be given to place it in any of the five genera discussed above. The intent of this paper is to describe our isolate as a new species in the genus which we consider to be most correct (Tapinothrix), determine the phylogenetic position of the isolate, and discuss the systematic and taxonomic ramifications of the discovery and characterization of this species, including reassignment of problematic species to what we consider to be the correct genera. While this may seem like an unusual case, it is likely representative of many similar stories that will be told as the revisionary process of the cyanobacteria continues.

\section{Materials and Methods}

Isolation and cultivation. A sample was collected in August 2006 from a sandstone seep wall adjacent to the cascade at Lower Calf Creek Falls in the Great Staircase-Escalante National Monument, Utah, USA $\left(37^{\circ} 49^{\prime} 44.77^{\prime \prime} \mathrm{N}, 111^{\circ} 25^{\prime} 12.58^{\prime \prime} \mathrm{W}\right)$ and kept refrigerated until further processing in laboratory.

A small, unmeasured portion of the sample was dilution plated onto agar-solidified Z8 universal algal culture medium (Kотаг 1972). Enrichment was completed under 16:8 light:dark cycle and corresponding day and night temperatures of $15{ }^{\circ} \mathrm{C}$ and $10^{\circ} \mathrm{C}$. Colonies were picked $4-6$ weeks later. The isolate discussed in this paper was a black cyanobacterial colony, and was isolated onto a Z8 slant. Morphological variability of the culture was determined by examining the culture as it aged from exponential growth phase through senescence (a period of about three months). Characterization was completed using an OLYMPUS BMAX 60 microscope with high resolution Nomarski DIC optics, equipped with a Spot digital camera. The cell dimensions were repeatedly measured using an ocular micrometer.

Molecular characterization. Tapinothrix was scraped from slants, and genomic DNA isolation was performed using the UltraClean Microbial DNA Isolation Kit from MO BIO (Carlsbad, CA, USA). DNA was eluted and stored at $-20^{\circ} \mathrm{C}$.

A PCR product of $1600 \mathrm{bps}$ containing the $16 \mathrm{~S}-$ 23S ITS was generated using primers 1 and 2 (BOYER et al. 2002). Fifty microliter reactions were performed in a Bio-Rad DNA Engine PTC200 (Hercules, CA, USA). Final concentrations of reagents in the reactions were 1X Taq polymerase buffer (USB, OH, USA), $1.5 \mathrm{mM} \mathrm{MgCl}, 2.5$ pmol per $\mu \mathrm{l}$ of each primer, $1 \mu \mathrm{l}$ of template DNA (100-200 ng total), $0.2 \mathrm{mM}$ dNTPs (USB), and 1.25 units Taq polymerase (USB).Cycling conditions were 35 cycles of $94{ }^{\circ} \mathrm{C}$ for $45 \mathrm{sec}, 57^{\circ} \mathrm{C}$ for $45 \mathrm{sec}$, and $72{ }^{\circ} \mathrm{C}$ for $135 \mathrm{sec}$. A $5 \mathrm{~min}$ extension at $72{ }^{\circ} \mathrm{C}$ was performed, and the reactions were held at $4^{\circ} \mathrm{C}$ indefinitely. All PCR products were analyzed on $1 \%$ agarose gels before being TA-cloned into the $\mathrm{pSC}-\mathrm{amp} / \mathrm{kan}$ plasmid of the Stratagene Cloning Kit (La Jolla, CA, USA). Putative clones were isolated using QIAprep Spin kits (Qiagen, Carlsbad, CA, USA) with elution in $50 \mu \mathrm{l}$ of sterile water. The presence of an insert was confirmed by EcoR I digestion.

Four 16S rRNA and 16S-23S ITS plasmids were sequenced by Functional Biosciences, Inc. (Madison, WI, USA) using the M13 forward and M13 reverse primers. Additionally, the 16S-23S ITS-containing plasmids were sequenced with internal primers 5 (5'-TGTACACACCGCCCGTC-3') and 8 (5'-AAGGAGGTGATCCAGCCACA-3') (FleChtner et al. 2002). Sequences were aligned and proofread using Sequencher software (version 4.8, Ann Arbor, MI, USA). Only one 16S-23S ITS operon was identified, the one that encodes both tRNA ${ }^{\text {Ile }}$ and tRNA $^{\text {Ala }}$. Subsequently, the folded secondary structures were determined using Mfold version 3.2; the default conditions were used in this analysis except for draw mode: untangle with loop fix. Conserved domains within the 16S-23S ITS were identified through employment of comparative analysis with the ITS of other Pseudanabaenales, particularly with respect to the basal portions of each helix. Structures were drawn in Adobe Illustrator CS4 prior to publication. 
Phylogenetic Analyses. In the first round of analyses reported in this paper, we selected a large group of nonheterocytous taxa to examine the phylogenetic position of our newly sequenced strain. A total of 272 sequences including representatives of Pseudanabaenaceae, Phormidiaceae, and Oscillatoriaceae were used in the first analysis. Sequences were aligned using CLUSTAL-W, and then proofed manually by eye. Secondary structure was consulted to align indels. Space does not permit listing the accession numbers of all strains used in this analysis, but single taxa shown in figures and tables are given with accession numbers. Based on the results of distance and parsimony analyses of this large data set, a smaller subset of taxa was selected to exclude taxa outside of the Pseudanabaenales as well as some isolates of uncertain affiliation (not identified at least to genus level). The final set for phylogenetic analysis contained 114 OTU's. Descriptions of the analyses using this data set are given below.

The GTR $+\mathrm{I}+$ gamma model was selected under the Akaike Information Criterion using PAUP* 4.0b10 (SwOFFord 2002) and Modeltest 3.7 (PosAdA $\&$ CRANDAll 1998) and was used for all model-based analyses. The software MrBayes 3.1.2 (HuELSENBECK
\& Ronquist 2001, Ronquist \& HuELSENBECK 2003) was used for Bayesian inference. A Dirichlet $(1,2,1,1,2,1)$ prior was used for the substitution rate parameters, a Dirichlet (2) prior was used for base frequencies, and a uniform (0,1 prior) was applied to the pinvar parameter. An exponential (1.0) prior was set on branch lengths and gamma shape parameters. Two runs were run for $10^{7}$ generations, using one cold chain and three heated chains and sampling every 100 trees. The first 40,000 samples of each run were discarded as a burn-in phase. The stability of model parameters and the convergence of the two runs were confirmed using Tracer v1.4.1 (RAmbaut \& DRummond 2003) and AWTY (Wilgenbusch et al. 2004). A maximum likelihood (ML) analysis was performed using Garli (ZwICKL 2006). A GTR+I+gamma model was applied and bootstrap support values obtained from 100 pseudoreplicate data sets. Additionally, an unweighted maximum parsimony analysis was carried out using PAUP* 4.0b10 (SwOFFORD 2002), and bootstrap supports were obtained from 1000 pseudoreplicate data sets. Trees were prepared for publication using Adobe Illustrator CS4.
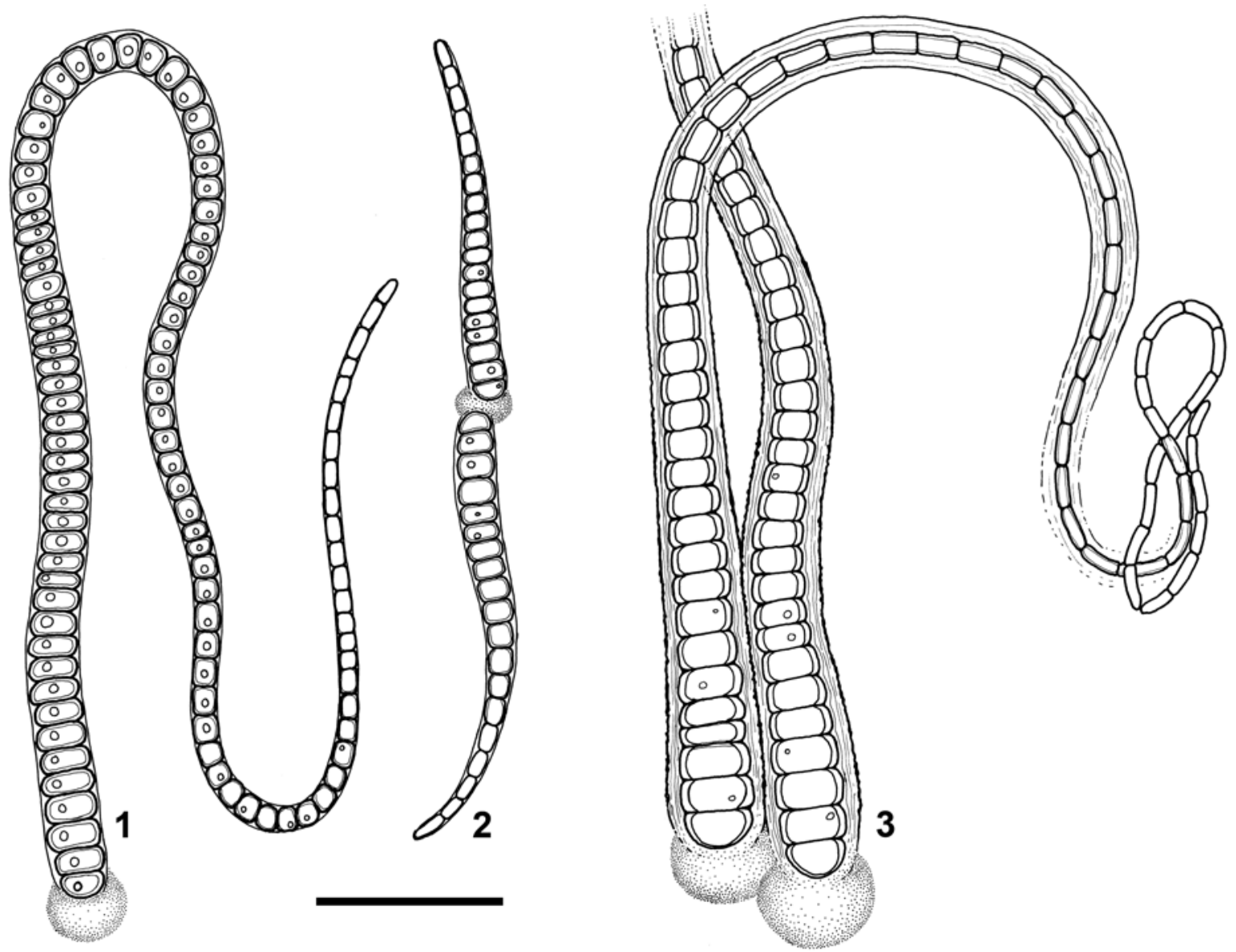

Figs 1-3. Morphological variability within Tapinothrix clintonii: (1) young tapered filament with thin sheath and mucilaginous pad at the base; (2) young filaments connected with common mucilaginous pad; (3) mature filaments with firm structured sheath and mucilaginous pad at the base. Scale bar $10 \mu \mathrm{m}$. 


\section{Results}

Tapinothrix clintonii BohUnická et Johansen, sp. nov. (Figs 1-29)

Diagnosis: Phormidiochaete fuscae maxime simile, a quo trichomate morina ad septum constricta, diametro latiore trichomae, habitatione paritum irrugarum in desertis differt. Homoeothrix violaceae (BORNET et Flahault) KomáreK et Kann simile, a quo diametro latiore trichomae, cellulis apicalibus elongatis et habitatione aquae dulcis differt.

Most similar to Phormidiochaete fusca, from which it differs by the purplish color of the trichomes, the distinctly constricted crosswalls, the wider trichome diameter, and habitat preference of desert seep walls. Also similar to Homoeothrix violacea, from which it differs by the wider trichome diameter, the elongated cells in the apical region, and habitat preference of freshwater.

Descriptio: Colonia junior badia morinescens expansa. Filamento juniora isopolaria et ad apices ambo decrescentia, in centro rumpens heteropolarescentia, ad maturitatem tumida ad basim ad apices decresentia, muco basali incolorato, interdum pseudoramosa. Vagina firma aspera incolorata vel morina nigrescens, 0.5-1 $\mu$ m lata. Trichomae ad basim et ad partem mediam constrictae ad septum, ad apices nonconstrictae ad septum, 3-4 um latae ad basim, ad apices 0.75-1 $\mu \mathrm{m}$ latescentes, in pilum terminantes. Cellulae ad basim latitudone breviora, cytoplasmate granuloso badio, thylakoidibus parietalibus, saepe granulato centrali amplo, 0.75-1.5 um longae. Cellulae ad apices cylindricae, sine vagina, pallide bruneorosae, latitudone longiora, 2-3 $\mu$ m longae.

Colony brown when young, becoming mulberryblack, spreading. Filaments isopolar and tapering to both apices when young, fragmenting centrally to become heteropolar with maturity, swollen at the base, tapered towards the ends, with colorless mucilaginous pad at the base of mature filaments, occasionally pseudobranched. Sheath firm, rough, colorless to blackish-purple to black, $0.5-1 \mu \mathrm{m}$ thick. Trichomes constricted at cross-walls in basal and median regions, not constricted towards the apices, 3-4 $\mu \mathrm{m}$ wide at the base, tapering to $0.75-1 \mu \mathrm{m}$ wide at the apices, ending in a hair. Cells at the base shorter than wide, with brownish granulated content, parietal thylakoids, often with a large central granule, $0.75-1.5 \mu \mathrm{m}$ long. Cells at the apices cylindrical, not enclosed in sheath, pale brownish-pink, longer than wide, $2-3 \mu \mathrm{m}$ long.

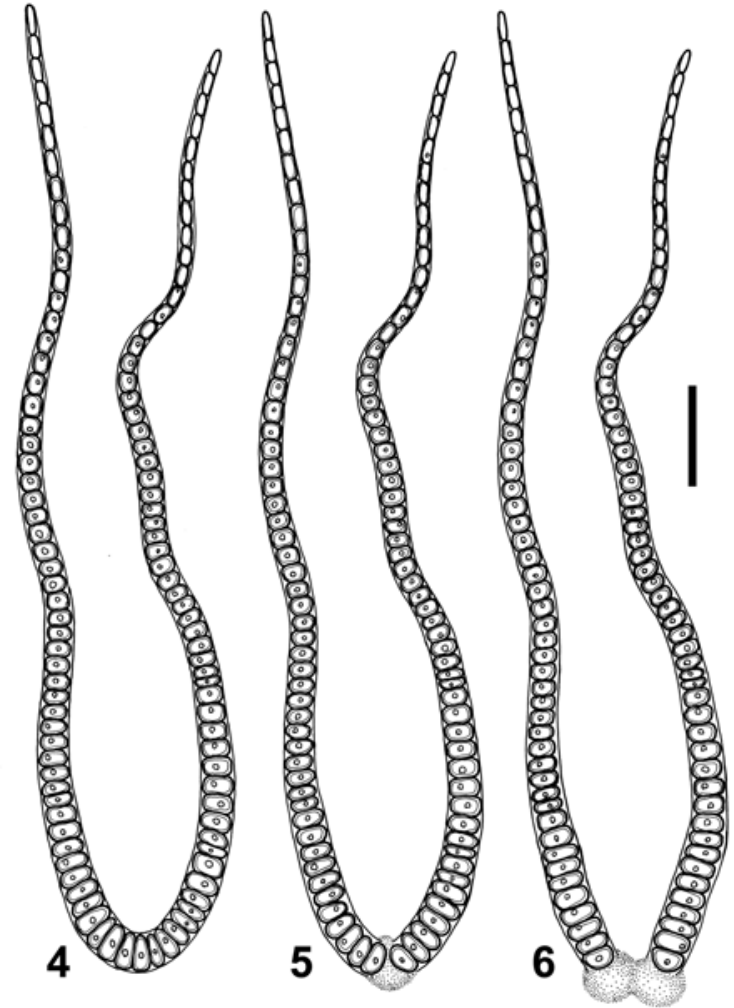

Figs 4-6. Development of heteropolar filaments with mucilaginous pad at the base in Tapinothrix clintonii: (4) young filament tapered towards both ends, bent in the middle part; (5) filament breaks in the middle part, mucilaginous pad forms; (6) two young heteropolar filaments with mucilaginous pads. Scale bar $10 \mu \mathrm{m}$.

Holotype here designated: BRY37705 (unialgal population preserved in 4\% formaldehyde), Herbarium of Nonvascular Cryptogams, Monte L. Bean Museum, Provo, Utah. Isotype materials included in the accession to BRY consisted of dried culture populations on filter paper (three filter papers, BRY37705).

Etymology: Tapinothrix clintonii $=$ Tapinothrix named in honor of President William Jefferson Clinton, in recognition of his efforts to provide protection for the ecosystems and landscapes now set aside in the Grand Staircase-Escalante National Monument.

Reference strain: Tapinothrix GSE-PSE06-07G (UTEX temporary no. B ZZ872, CCALA 940).

\section{Life cycle}

Young filaments were observed to be tapered towards both ends, with a width of around 3.5 $\mu \mathrm{m}$ in the central, thickest part. These isopolar filaments apparently break in the middle to form two filaments attached to each other at the base by the mucilaginous disk (Figs 3, 4-6, 18, 20, 28). 

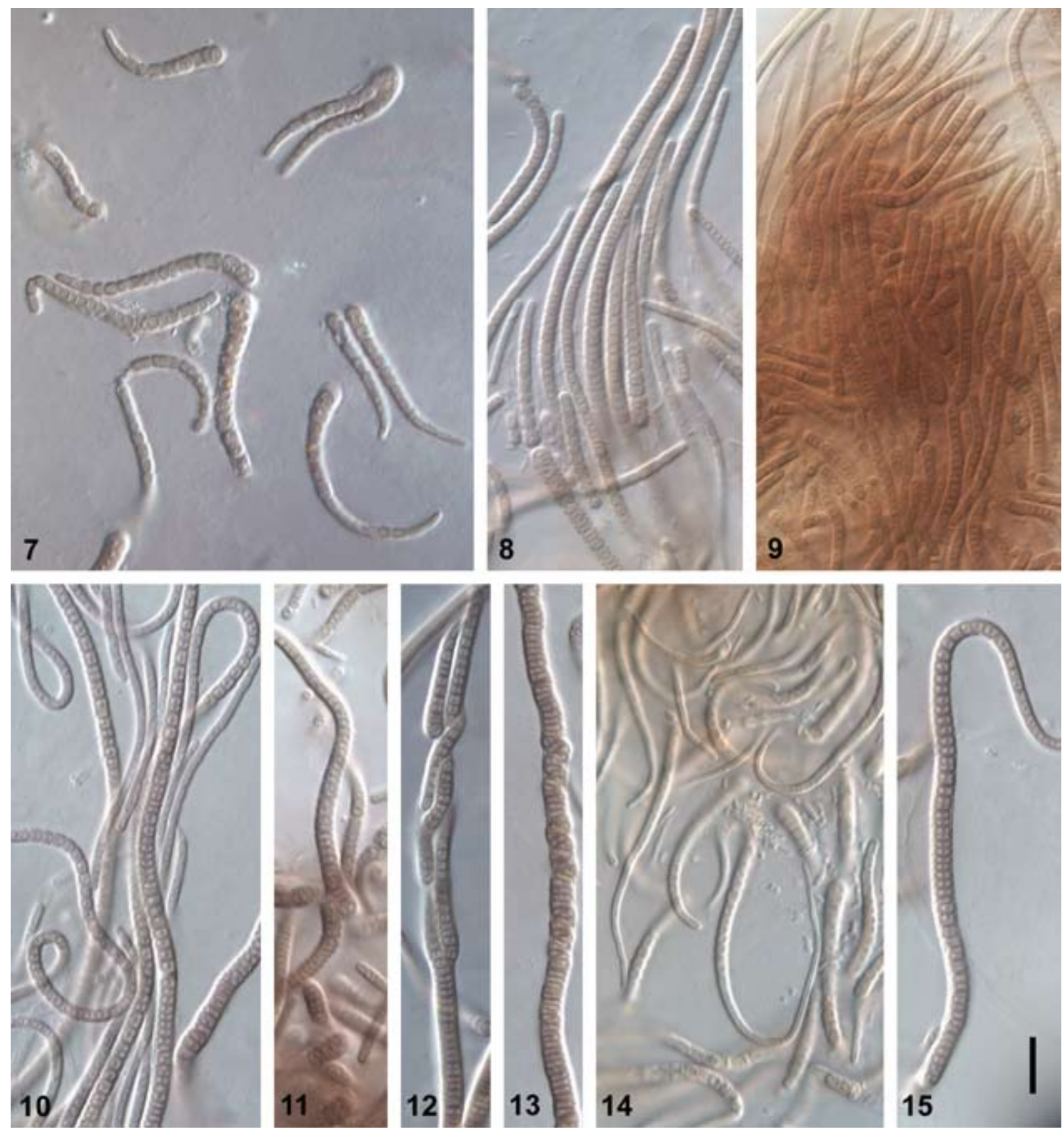

Figs 7-15. Tapinothrix clintonii, young filaments: (7) short young filaments breaking in the middle part; (8) young filaments swollen at the base, with no clear sheath; (9) very young Leptolyngbya-like filaments, not tapered; (10) middle part of long young filaments, central granules visible; (11) young filament breaking in the middle part; (12) middle part of long filament with irregular cells; (13) false branching; (14) tapering of young filaments; (15) young tapered filament. Scale bar $10 \mu \mathrm{m}$.

This process of fragmentation leads to formation of star-like colonies, with many swollen ends in the center and tapering ends extending out of the clump (Figs 22, 23). Young filaments have colorless or faintly purplish sheaths. The sheath becomes blackish-purple to black as the culture ages (Fig. 29). Colony on agar is brown to black.

\section{Comparisons to other taxa}

Most Tapinothrix taxa taper only very slightly (often not at all), and form grass-like turfs of upright filaments on hard surfaces (rocks). They are clearly members of the Pseudanabaenales in subclass Synechococcophycidae, based on cell diameter and peripheral thylakoid arrangement. Many are associated with a basal community of Chroococcus or Pleurocapsa species, and this association led to the incorrectly conceived and now abandoned genus Amphithrix (e.g. Amphithrix janthina Bornet et Flahault). Most species of Tapinothrix were originally described as members 

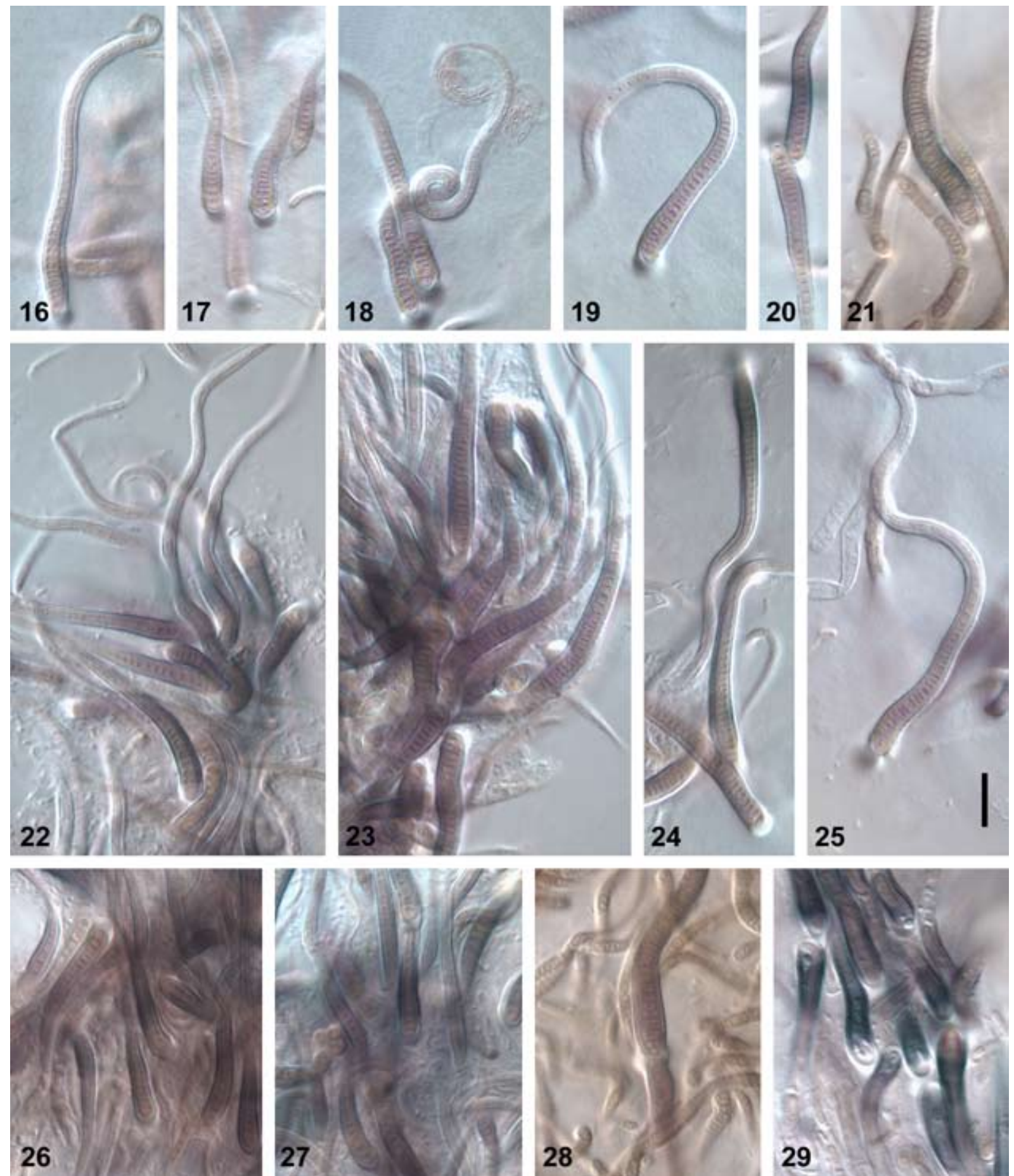

Figs 16-29. Tapinothrix clintonii, mature filaments: (16-21) mature filaments swollen at the base, with thick, structured, blackish sheath; (22-23) star-like colonies, with many swollen ends in the center and tapering ends extending out of the clump; (24-25) long mature filaments with thick, structured, colored sheath; (26-27) old, mat-like colonies; (28) two mature filaments connected with one mucilaginous pad; (29) very old colony with black sheaths. Scale bar $10 \mu \mathrm{m}$.

of the genus Homoeothrix, but the type species of that genus, Homoeothrix juliana (BORNET et Flahault) Kirchner, clearly belongs in the Oscillatoriaceae in subclass Oscillatoriophycidae (based on cell diameter and irregular thylakoid arrangement).

Our strain was growing on a rock surface, and likely had the typical heteropolar, basally attached filaments in nature. However, we did not see Tapinothrix clintonii in the natural material, and suspect that it was very rare in the original sample. Most species of Tapinothrix are pale greyish blue-green in color, and the brownish and purplish colors this strain possesses even in culture 
are fairly distinctive. Homoeothrix violacea is one of the purplish species previously described, but is narrower at the base and has shorter cells in the terminal regions. Most importantly, $H$. violacea is a marine taxon. Homoeothrix fusca can be yellowish or blackish, but has blue-green trichomes, is not constricted or at most weakly constricted at the crosswalls, and is also narrower. Ecological separation for this taxon is also strong; H. fusca is reported to be xeno- to oligosaprobic in clear mountain waters, while $T$. clintonii was found in a warm desert seep wall associated with a stream flowing through cattle country (i.e., not oligosaprobic!).

Tapinothrix is likely most easily confused with species of Heteroleibleinia, which are heteropolar, attached at the base, but never tapering. The latter genus also seems consistently epiphytic rather than epilithic. Neither genus has been sequenced up until this time, and almost certainly confusion will surround these taxa until collection and analysis of sequence data is completed. There are no Heteroleibleinia species that could be confused with $T$. clintonii.

\section{Phylogenetic placement}

Tapinothrix clintonii and Leptolyngbya sensu stricto (the group of taxa associated with Leptolyngbya boryana, the type species of the genus) belong to the same clade (Clade A, Fig. 30). A strain possessing the morphology of Leptolyngbya, GSE-PSE30-01B may be sister to Tapinothrix, but there is poor support for this putative relationship. A number of Pseudophormidium strains belong to Clade B (Fig. 30). These strains are wider than most Leptolyngbya, and demonstrate multiple trichomes in a sheath with frequent false branching. Other clades contain mostly putative Leptolyngbya (Clades C, D, E and G). Clade F (Fig. 30) contains many taxa of uncertain placement in the LPP groups, along with some well established species and genera, such as Halomicronema excentricum ABED, GARCIAPichel et Hernández-Mariné, Prochlorothrix hollandica Burger-Wiersma, Stal et Mur and Leptolyngbya nodulosa Li et BRAND. Finally, Clade $\mathrm{H}$ contains a mixture of strains assigned to Pseudanabaena (10 OTU's), Limnothrix redekei (3 OTU's), and Synechococcus (1 OTU).

If the identification of the strains in this tree were made correctly (and we are not confident that they all were made consistent with KOMÁREK $\&$ ANAGNOSTIDIS 2005), then a number of genera are polyphyletic, including Synechococcus (Clades $\mathrm{F}$ and $\mathrm{H}$ ), Limnothrix redekei (Clades F and $\mathrm{H}$ ), Pseudanabaena (Clades $\mathrm{D}$ and $\mathrm{H}$ ) and Leptolyngbya (Clades A, C, D, E, F, G). The strain identified as Phormidium (Clade F) is certainly incorrectly identified.

\section{ITS structural comparisons}

In cyanobacteria, the D1-D1' helix is the most conserved structure of the 16S-23S ITS region (Johansen et al. 2008). In all Pseudanabaenales examined to date, this helix contains a 5 bp basal helix (GACCU:AGGTC), a unilateral bulge of 5-8 nucleotides on the 3' side, followed by a $3 \mathrm{bp}$ helix (ACC:GGU - except Pseudanabaena GSEPSE20-05C and Leptolyngbya appalachiana GSM-SFF-MF60 which differ in sequence). A bilateral bulge or unilateral bulge comes next, with the rest of the helix being too variable to recognize a common pattern (Figs 31-43). Apart from these similarities, we did find further consistencies within the various LPP clades.

The clade consisting of 12 OTU's in Leptolyngbya sensu stricto includes Leptolyngbya boryana, $L$. tenerrima, and a number of unidentified species/strains. Of these 12, we have ITS sequences for eight strains, and all were markedly similar in secondary structure of the D1-D1' helix to the two strains chosen to represent this group (Figs 31,32). This group of taxa all has sequences of 51 nucleotides, with a terminal loop of four unpaired nucleotides, a small irregularity caused by an adenosine residue that does not pair, and a basal unilateral bulge of only 5 nucleotides (Figs 31, 32). Leptolyngbya crispata which fell outside of Leptolyngbya sensu stricto, had a markedly similar D1-D1' helix to this clade (Fig. 33). The desert soil strains of Leptolyngbya had more variability in structure in this region than L. sensu stricto, and differed in several regards: a basal bilateral bulge of 7 nucleotides, the loss of the mid-helix bulge, and a larger terminal loop (Figs 34, 35).

The taxon sister to T. clintonii according to the phylogenetic analysis, Leptolyngbya GSEPSE30-01B, had a strikingly different D1-D1' helix (Fig. 36). T. clintonii was similar to this strain in the basal part of the helix (Fig. 37), particularly with respect to the adenosine residue inserted opposite the unilateral bulge on the 3 ' part of the helix (a feature so far unique for this clade). The more terminal part of this helix was similar in length to those of Leptolyngbya sensu stricto, 


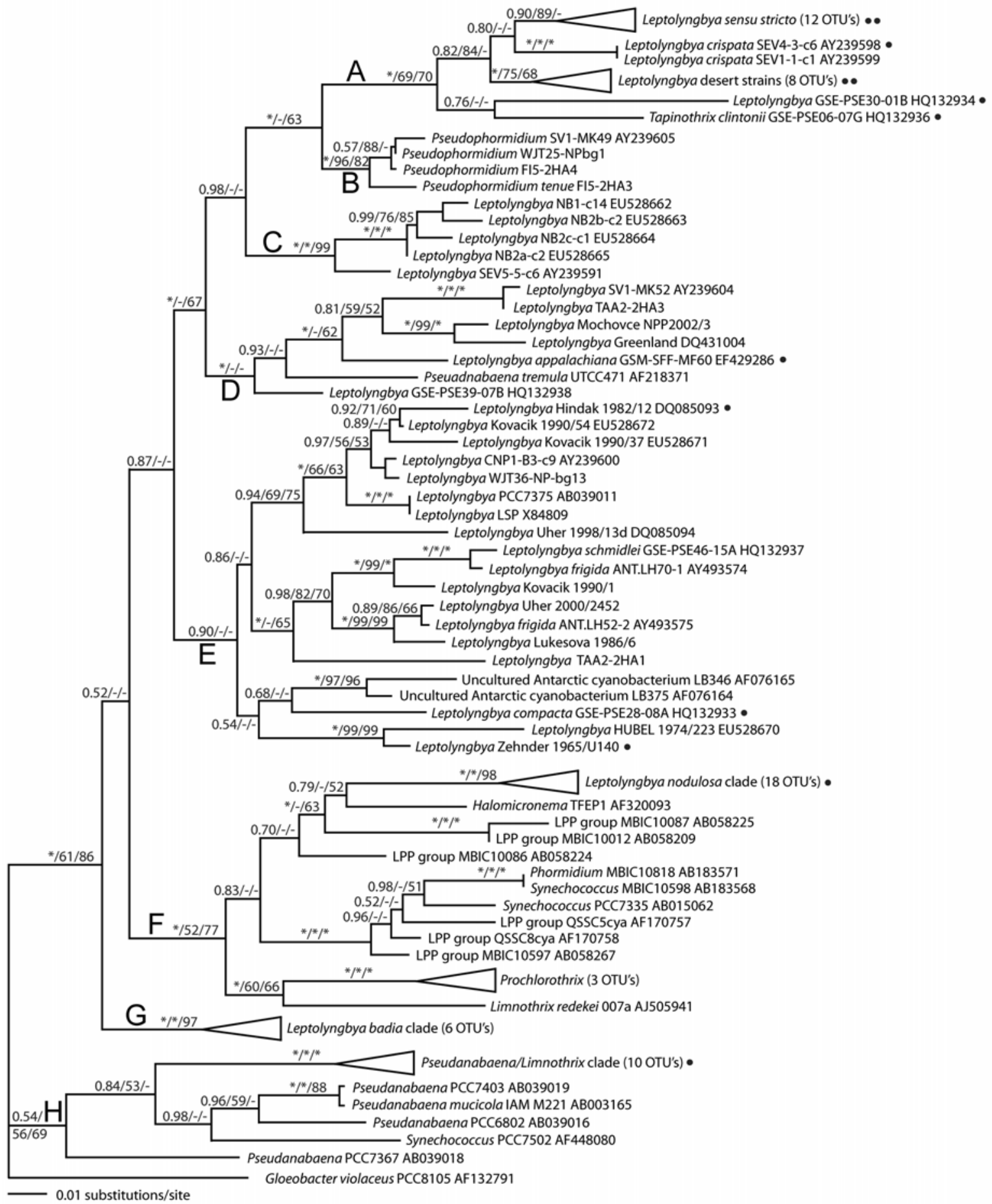

Fig. 30. Bayesian analysis of 113 OTU's of Pseudanabaenales plus Gloeobacter violaceus from the Gloeobacteriales. Node support is indicated as Bayesian posterior probabilities/bootstrap support from parsimony analysis/bootstrap support from likelihood analysis; an * means 1.0 or $100 \%$, a - means support less than 0.50 or $50 \%$. Major clades are indicated by letters $(\mathrm{A}-\mathrm{H})$. Black dots at the end of OTU names or sets of OTU's indicate that ITS structures were available and are shown in Figs $31-65$.

but the sequence was markedly different in both the helix and terminal loop. The D1-D1' helix in strains more distantly related to Leptolyngbya sensu stricto had larger terminal loops, or a terminal loop subtended by a bilateral bulge (Figs 38-42) .
Leptolyngbya appalachiana had an unusually long D1-D1' helix (Fig. 43), and differed from all other taxa in the Pseudanabaenales sequenced thus far.

The Box-B antiterminator helix in Tapino- 


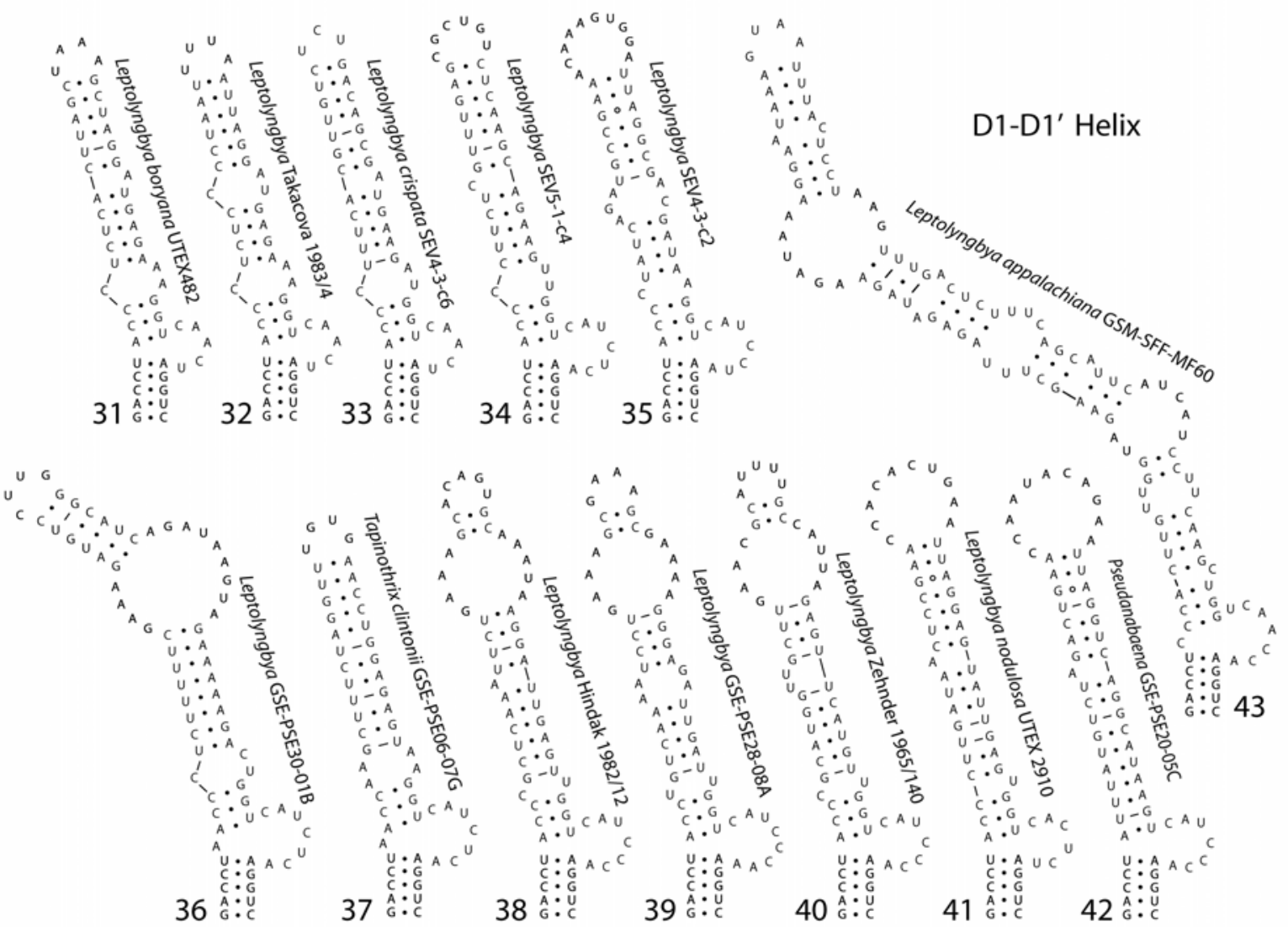

Figs 31-43. Secondary structure of the D1-D1' helix from the 16S-23S ITS region in several OTU's representing various Pseudanabaenalean clades, arranged in the order (top to bottom) they appear in the Bayesian analysis (Fig. 30): (31-32) Leptolyngbya sensu stricto, including the type species, Leptolyngbya boryana. This structure was seen in nearly all strains in this clade; (33-35) Leptolyngbya spp. from desert soils in New Mexico; (36) Leptolyngbya sp. with untapered, reddish colored trichomes from wet wall in Grand Staircase-Escalante National Monument; (37) Tapinothrix clintonii; (38-40) Leptolyngbya spp. from clade E (with cells longer than wide, see center, Fig. 30); (41) Leptolyngbya nodulosa UTEX2910, representing the L. nodulosa clade and clade F (Fig. 30); (42) Pseudanabaena sp. representing a clade of 10 OTU's (clade H, Fig. 30); (43) Leptolyngbya appalachiana, a species with exceptionally long helices in all conserved helices of the 16S-23S ITS (clade D, Fig. 30).

thrix clintonii was distinct from all other Box-B helices. This region is more variable than the D1D1' helix, as evidenced by the different lengths and different placement of unilateral and bilateral bulges (Figs 44-56). The basal structure is more conserved, and this is the region different in Tapinothrix (Fig. 50). Most strains have a basal bilateral bulge above the initial helix $(\mathrm{A}-\mathrm{CC})$, whereas Tapinothrix has a unilateral double uracil insert on the 5 ' side of the helix. Leptolyngbya GSE-PSE28-08A and Leptolyngbya appalachiana had distinctively long helices that were also different than the Box-B regions of other strains.

The V3 helix is the most difficult structure to determine because its length is dependent on the length of the D4 and D5 helices. These latter two helices can only be determined with confidence when the 23S-5S ITS structure is sequenced and available. We did have this sequence for Tapinothrix so we are confident in this V3 structure (Fig. 60). The V3 for all taxa in Leptolyngbya sensu stricto (including L. crispata SEV4-3-c6) were identical in sequence and structure (Fig. 57). Surprisingly, the V3 helix for L. crispata SEV43-c2 (Fig. 58) was very different than $L$. crispata SEV4-3-c6 despite their close relationship inferred from the 16S rRNA phylogeny (Fig. 30). It seems possible this is due to sampling different ribosomal operons. Tapinothrix has a unique V3 among all taxa characterized (Fig. 60), with the base of the helix (the most conserved part of most helices) very distinct (5'GGU-ACC3') from the typical base (5'UGUC-GACA3'). Its putative sister taxon, Leptolyngbya GSE-PSE30-01B, also had a unique structure for the V3 among 


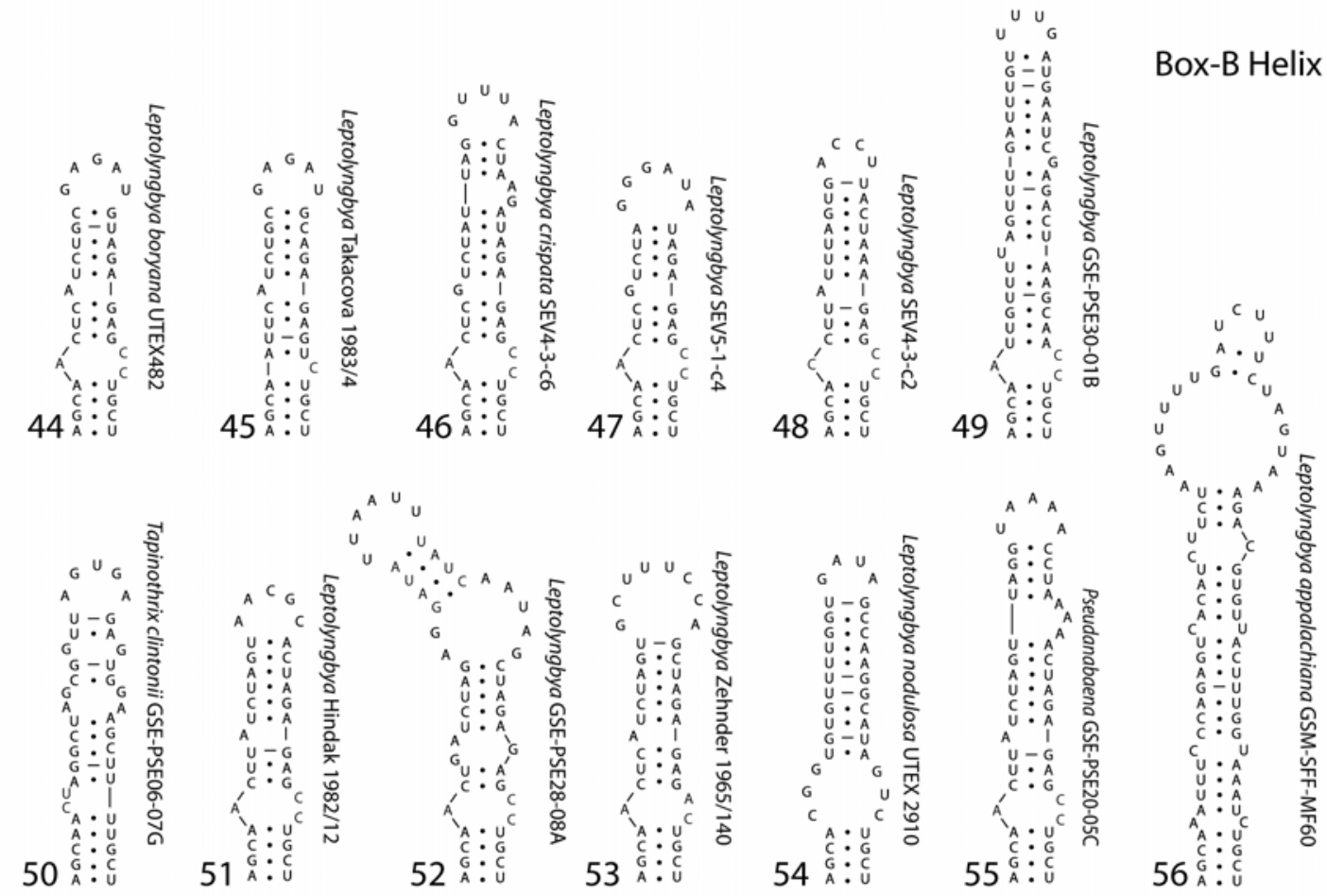

Figs 44-56. Secondary structure of the Box-B helix from the 16S-23S ITS region in several OTU's representing various Pseudanabaenalean clades, arranged in the order (top to bottom) they appear in the Bayesian analysis (Fig. 30).

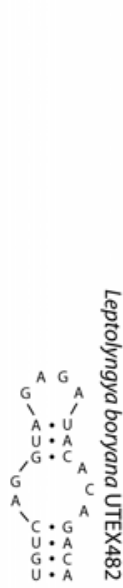

57

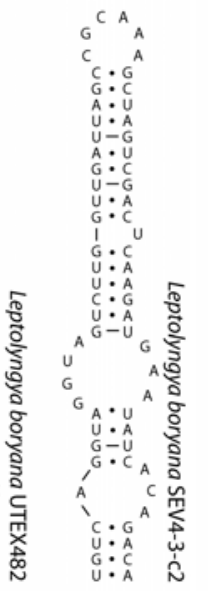

58

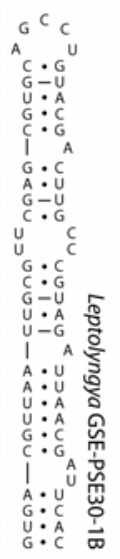

59

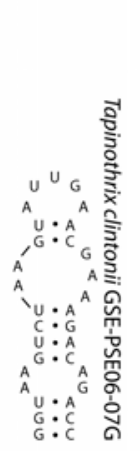

60

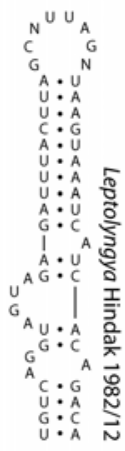

61

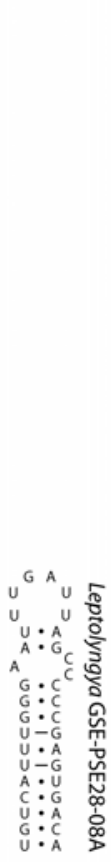

62

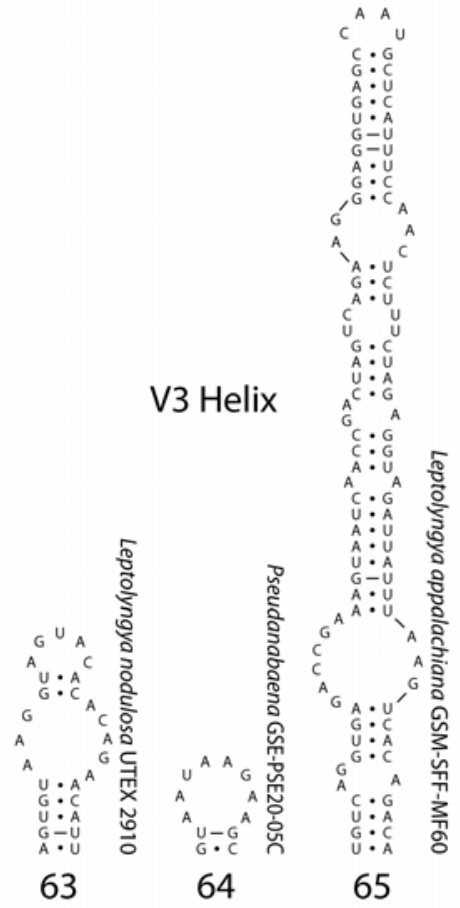

Figs 57-65. Secondary structure of the V3 helix from the 16S-23S ITS region in several OTU's representing various Pseudanabaenalean clades, arranged in the order (top to bottom) they appear in the Bayesian analysis (Fig. 30). 
the sampled strains (Fig. 59). The remaining V3 helices were all unique (Figs 61-65), save for that of Leptolyngbya nodulosa UTEX2910. We have several sequences of strains in this clade, and they all have the same V3 helix (data not shown).

\section{Nomenclatural revision of Homoeothrix species}

We recommend that all of the Homoeothrix species clearly belonging to the Pseudanabaenaceae be transferred to Tapinothrix. While KOMÁREK \& ANAGNostidis (2005) recommended that this revision occur, they felt that further work (cytological, morphological, and molecular) should be completed. The present work supports the hypothesis that these taxa are not in the Oscillatoriaceae, and further confusion will be experienced until the taxonomy is complete. Revisionary work is still needed in this genus, as many of the species overlap in morphology, and differentiation and identification are problematic. Currently, no living strains exist for any species of Tapinothrix or Homoeothrix except T. clintonii.

Based on its morphology, Phormidiochaete fusca (= Homoeothrix fusca) is the likely sister taxon of $T$. clintonii. It has similar cell measurements, but differs in the amount of constriction at the crosswalls, the trichome color, and habitat preference. This taxon should surely be in Tapinothrix, and the transfer is made below.

A few of the Homoeothrix species do not belong in the Pseudanabaenaceae or Oscillatoriaceae, and therefore correspond best with Phormidiochaete in the Phormidiaceae. $H$. margalefii KoMÁREK et KALINA has trichomes up to $7 \mu \mathrm{m}$ wide at the base and filaments up to $8.5 \mu \mathrm{m}$ wide. This species is transferred below as well.

\section{Phormidiochaete crustacea (BoRzì ex BoRNET et} Flahault) Bohunická et Johansen, comb. nov. Basionym: Leptochaete crustacea Borzì ex BORNET et Flahault (1886-1888, ser. 3, p. 342).

Synonyms: Homoeothrix crustacea (Borzì ex Bornet et Flahault) Margalef (1953), Homoeothrix margalefii KomÁreK et Kalina (1965), non Homoeothrix crustacea Voronichin (1923).

Tapinothrix articulata (STARMACH) BOHUNICKÁ et Johansen, comb. nov.

Basionym: Homoeothrix articulata StARMACH (1960, p. 231).

\section{Tapinothrix batrachospermorum}

(SKUJA)

BohUnická et Johansen, comb. nov.

Basionym: Homoeothrix batrachospermorum Skuja (1964, p. 68).
Tapinothrix calcarea (LI) BOHUNICKÁ et JoHANSEN, comb. nov.

Basionym: Homoeothrix calcarea Li (1994, p. 70).

Tapinothrix crustacea (VoRONICHIN) BOHUNICKÁ et Johansen, comb. nov.

Basionym: Homoeothrix crustacea Voronichin (1923, p. 115).

Synonyms: Homoeothrix globulus VoRONICHIN (1932), Homoeothrix woronochinii Margalef (1953); non Homoeothrix crustacea (Borzi) Margalef (1953).

Tapinothrix fusca (STARMACH) BoHUNICKÁ et Johansen, comb. nov.

Basionym: Homoeothrix fusca Starmach (1934, p. 294).

Synonym: Phormidiochaete fusca (StARmach) KomÁreK et ANAGNostidis.

Tapinothrix gloeophila (STARMACH) BOHUNICKÁ et Johansen, comb. nov.

Basionym: Homoeothrix gloeophila Starmach (1960, p. 227).

Tapinothrix gracilis (HANSGIRG) BOHUNICKÁ et JoHANSEN, comb. nov.

Basionym: Leptochaete crustacea var. gracilis HANSGIRG (1892b, p. 138).

Synonyms: Leptochaete gracilis (HANSGIRG) GeItLeR (1925), Homoeothrix gracilis (HANSGirg) KomÁReK \& KovÁČIK (1987).

Tapinothrix janthina (Bornet et Flahault) BohUnická et Johansen, comb. nov.

Basionym: Amphithrix janthina Bornet et Flahault (1886-1888, ser. 3, p. 344).

Synonym: Homoeothrix janthina (Bornet et FlaHAUlT) STARMACH (1959).

Tapinothrix minuta (SECKT) BoHUNICKÁ et JoHANSEN, comb. nov.

Basionym: Homoeothrix minuta SЕскт (1921, p. 425).

Tapinothrix poljanskii (MUZAFAROv) BoHUnICKÁ et Johansen, comb. nov.

Basionym: Homoeothrix poljanskii MuZAFarov (1952, p. 84).

Synonym: Homoeothrix schizotrichoides Muzafarov (1952).

Tapinothrix rivularis (HANSGIRG) BoHUNICKÁ et JOHANSEN, comb. nov.

Basionym: Leptochaete rivularis HANSGIRG (1892a, p. 54).

Synonym: Homoeothrix rivularis (HANSGIRG) KOMÁREK et KANN (1973).

Tapinothrix simplex (VoRONICHIN) BOHUNICKÁ et JoHANSEN, comb. nov.

Basionym: Homoeothrix simplex VorONICHIN (1932, p. 309).

Tapinothrix stagnalis (HANSGIRG) BOHUNICKÁ et JoHANSEN, comb. nov. 
Basionym: Leptochaete stagnalis HANSGIRG (1892a, p. 54).

Synonym: Homoeothrix stagnalis (HANSGIRG) KOMÁREK et KovéčiK (1987).

Tapinothrix subtilis (SKUJA) BoHUNICKÁ et JoHANSEN, comb. nov.

Basionym: Homoeothrix subtilis SKUJA (1964, p. 69).

Tapinothrix varians (GeITLER) BOHUNICKÁ et Johansen, comb. nov.

Basionym: Homoeothrix varians GeITLER (1927, p. 801).

Synonyms: Homoeothrix simplex var. elegans Voronichin (1932), Homoeothrix simplex f. elegans (Voronichin) Elenkin (1949).

Tapinothrix violacea (Bornet et Flahault) BohUnická et Johansen, comb. nov.

Basionym: Amphithrix violacea Bornet et Flahault (1886-1888, ser. 3, p. 344).

Synonym: Homoeothrix violacea (BorNET et FlaHAULT) KOMÁreK et KANN (1973).

\section{Discussion}

Tapinothrix clintonii shares characteristics with five different genera. To our knowledge, the unusual feature of forming trichomes which taper towards both apices is restricted to Ammatoidea (KomÁrek \& ANAgnostidis 2005). However, this taxon is based on a type species (A. normannii West et G.S. WeSt) clearly belonging to the Phormidiaceae. Phormidiochaete possesses heteropolar trichomes that taper from the attached base to the apex, but it too belongs in the Phormidiaceae. The source of confusion between Tapinothrix and these two genera is that some species belonging to the Pseudanabaenaceae apparently have been transferred into these genera erroneously. While $T$. clintonii has features similar to these taxa, it clearly belongs in neither because of its phylogenetic placement in the Pseudanabaenales. Phormidiochaete can rarely form isopolar trichomes that are Ammatoidealike, and these taxa may not be well separated.

Homoeothrix is a relatively species-rich taxon with a long nomenclatural history. No representative of Homoeothrix juliana has been sequenced to date, but it possesses the dimensions, cell-division pattern, and thylaloid arrangement consistent with the Oscillatoriaceae. The pseudanabaenalean taxa in Homoeothrix are likely very phylogenetically distant from the type species. We have placed the majority of these taxa in Tapinothrix, a genus which still needs considerable study and revision. These taxa are actually fairly common in unpolluted streams with rocky benthos, forming tufted fascicles of filaments.

Leptolyngbya GSE-PSE30-01B appeared to be the sister taxon to Tapinothrix clintonii. However, the two strains did not share high sequence similarity in the 16S rRNA gene ( $P$ $=91.1 \%$ ), did not have similar 16S-23S ITS secondary structures, and were dissimilar in morphology. We assume that this may be a case of long-branch attraction. Tapinothrix actually has highest sequence similarity to Leptolyngbya sensu stricto $(\mathrm{P}=92.4-93.6 \%)$, although this is still too low for it to be considered to belong to that genus since $<95 \%$ similarity is often considered to be the cut-off for indication of different genera.

This paper reports the first sequence attributed to the genus Tapinothrix, a taxon fairly common in clean to slightly enriched mountain streams (KoMÁREK \& KANN 1973). While common, the genus is not easy to obtain in culture as it often appears in an epilithic mat with many other taxa, and likely requires flowing water to develop its characteristic heteropolar, tapering morphology. In examination of other Tapinothrix in North America, JoHANSEN et al. (2011) found three species of Tapinothrix: T. varians, T. janthina, and a species new to science, T. ozarkiana JOHANSEN et ŘEHÁKOVÁ. They noted that species of Tapinothrix were difficult to differentiate and that more species might indeed be represented in the populations which they examined. Some species of Tapinothrix taper very little, and consequently resemble the epiphytic genus, Heteroleibleinia. The phylogenetic relationships of these taxa need determination. It seems possible that more than one tapering genus may be present within the Pseudanabaenaceae.

\section{Acknowledgements}

We thank the Bioinformatics Facility in the University of Connecticut Biotechnology Center for use of their computing cluster and Terry Tolbert, Liliya Khaibullina, and Lira Gaysina for help and support during the collection field trip. The project was supported by MSM 6007665801 and GAJU 135/2010/P grants.

\section{References}

Albertano, P. \& KováčiK, L. (1994): Is the genus Leptolyngbya (Cyanophyta) a homogenous 
taxon? - Arch. Hydrobiol./Algological Studies 75: 37-51.

AnAgnostidis, K. (2001): Nomenclatural changes in cyanoprokaryotic order Oscillatoriales. - Preslia 73: $359-375$

Borge, O. (1923): Beiträge zur Algenflora von Schweden III. - Arkiv för Botanik 18: 1-34.

Bornet, E. \& Flahault, C. (1886-1888): Revisions des Nostocacées hétérocystées. - Ann. Sci. Nat. Bot. Biol. 7, Ser. 3: 323-381, 4: 343-373, 5: 51-129, 7: 177-262. [Reprint 1959, J. Crammer, Weinheim]

Boyer, S.L., JohANSEN, J.R., FLeChTNER, V.R. \& HowARD, G. L. (2002): Phylogeny and genetic variance in terrestrial Microcoleus (Cyanophyceae) species based on sequence analysis of the $16 \mathrm{~S}$ rRNA gene and associated $16 \mathrm{~S}-23 \mathrm{~S}$ ITS region. $-\mathrm{J}$. Phycol. 38: 1222-1235.

Casamatta, D.A., Johansen, J.R., Vis, M.L. \& BROADWATER, S.T. (2005): Molecular and ultrastructural characterization of ten polar and near-polar strains within the Oscillatoriales (Cyanobacteria). - J. Phycol. 41: 421-438.

Castenholz, R.W. (2001): General characteristics of the cyanobacteria. - In: Boone, D.R. \& Castenholz, R.W. (eds): Bergey's Manual of Systematic Bacteriology, $2^{\text {nd }}$ ed., vol. 1. - pp. 474-487, Springer, New York.

Elenkin, A.A. (1949): Monographia algarum cyanophycearum aquidulcidum et terrestrium in finibus URSS inventarum (Sinezelenye vodorosli SSSR), Pars Specialis (Systematica) 2. - 1908 pp., Akademia Nauk SSSR, MoskvaLeningrad. [In Russian]

Flechtner, V.R., Boyer, S.L. \& Johansen, J.R. (2002): Spirirestis rafaelensis gen. et sp. nov. (Cyanophyceae), a new cyanobacterial genus from arid soils. - Nova Hedwigia 74:1-24.

Geitler, L. (1925): Cyanophyceae. - In: Pascher, A. (ed.): Die Süsswasserflora Deutschlands, Österreichs und der Schweiz, vol. 12. - 450 pp., Gustav Fischer, Jena.

Geitler, L. (1927): Über Vegetationsfärbungen in Bächen. - Biologia Generalis 3: 791-814.

Hansgirg, A. (1892a): Prodromus der Algenflora von Böhmen II. - 268 pp., Komissons-Verlag von Fr. Hřivnáč - Prag. [Reprint in Bibliotheca Phycologica vol. 27b, 1976]

Hansgirg, A. (1892b): Beträge zur Kenntniss der Süsswasseralgen und Baterienflora von Tirol und Böhmen. - Sitzungsberichte der Königlich böhmische Gesellschaft der Wissenschaften, Mathematisch - Natürwissenschaftliche Klasse, Prag: 105-156.

Huelsenbeck, J.P. \& Ronquist, F. (2001): MrBayes: Bayesian inference of phylogeny. Bioinformatics 17: 754-755.

Johansen, J.R., Olsen, C.E., Lowe, R.L., FučíkovÁ,
K. \& Casamatta, D.A. (2008): Leptolyngbya species from selected seep walls in the Great Smoky Mountains National Park. - Algological Studies 126: 21-36.

Johansen, J.R., ŘehÁKovÁ, K. \& Acker, F. (2011): Tapinothrix ozarkiana sp. nov., with notes on distribution for the genus in North America. Fottea 11: 141-148.

KirCHNER, O. (1898): Schizophyceae. - In: ENGLER, A. \& Prantl, K. (eds): Die natürlichen Pflanzenfamilien, Teil I, Abt. 1a. - pp. 4-92, Wilhelm Engelmann, Leipzig.

KomÁreK, J. \& AnAGNOSTIDis, K. (2005): Cyanoprokaryota 2. Oscillatoriales. - In: BÜDEL, B., Gärtner, G., Krienitz, L. \& Schlagerl, M. (eds): Süßwasserflora von Mitteleuropa 19/2. 760 pp., Elsevier GmbH, München.

KomÁReK, J. \& KalinA, T. (1965): Bemerkungen zur Cönologie und Systematik der Gattung Homoeothrix (Thur. ex Born. et Flah.) Kirchn. - Österr. Bot. Z. 112: 424-441.

KomÁrek, J. \& Kann, E. (1973): Zur Taxonomie un Ökologie der Gattung Homoeothrix. - Archives für Protistenkunde 115: 173-233.

KomÁReK, J. \& KovÁČIK, L. (1987): Revision of several species of the genus Homoeothrix (Cyanophytes). - Preslia 59: 229-242.

Kotai, J. (1972): Instructions for preparation of modified nutrient solution Z8 for algae. Norwegian Institute for Water Research, publication B-11/69, Oslo, Blindern.

KrautovÁ, M. (2008): Cyanobacteria of wet walls and seeps in Grand Staircase-Escalante National Monument, Utah. - 157 pp., M.S. Thesis, John Carroll University.

LI, Y. (1994): Study on the blue-green algae of Wuling Mountain Region. - In: SHI Z., WEI Y., LI Y., Zhu H., Li R. \& Yaо Y. (eds): Compilation of the reports on the survey of algal resources in south-western China. - pp. 51-74, Science Press, Beijing. [In Chinese]

Mabille, J. (1954): Homoeothrix Bornetii (Sauvageau) nov. comb. - Tapinothrix Bornetii (Sauv.). Review of Algology, N.S. 1: 1-13.

Margalef, R. (1953): Materiales para una flora de las algas del NE de España IVb, Cyanophyceae. Collectanea Botanica, Barcelona 3: 231-260.

Muzafarov, A.M. (1952): Neue Algen aus Berggewässern von Mittelasien.-Botanicheskie Materialy Otdela Sporovych Rastenij 8: 72-87.

Petrov, J.E. (1961): Cyanophyceae maritimae novae e Murmano. - Botanicheskie Materialy Otdela Sporovych Rastenij 14: 107-111. [In Russian]

Posada, D. \& Crandall, K.A. (1998): Modeltest: testing the model of DNA substitution. Bioinformatics 14: 817-818.

Rambaut, A. \& Drummond, A. (2003): Tracer: MCMC trace analysis tool. - University of Oxford; 
Oxford, UK.

Ronquist, F. \& Huelsenbeck, J.P. (2003): MrBayes 3: Bayesian phylogenetic inference under mixed models. - Bioinformatics 19: 1572-1574.

Sauvageau, C. (1892): Sur les algues d'eau douce récoltées en Algérie. - B. Soc. Bot. Fr. 39: 115117.

SECKT, H. (1921): Estudios hidrobiológicos en la Argentina. Schizophyceae. - Boletín Academia Nacional de Ciencias en Cordóba 25: 383-429.

SkujA, H. (1964): Grundzüge der Algenflora und Algenvegetation der Fjeldgegenden um Abisco in Schwedish-Lappland. - Nova acta Regiae Societatis Scientiarum Upsaliensis, serv. IV, 18: $1-462$.

Starmach, K. (1934): Dwa nowe Gatunki sinic z Tatr. - Acta Societas Botanicorum Poloniae 11: 287297.

StARMACH, K. (1959): Homeothrix janthina (Born. et Flah.) comb. nova mihi (= Amphithrix janthina Born. et Flah.) oraz sinice towarzyszące Homeothrix janthina (Born. et Flah.) comb. nova mihi (= Amphithrix janthina Born. et Flah.) and associating it Blue-green algae. Acta Hydrobiologica 1: 149-164.

StARMACH, K. (1960): Dwa nowe gatunki sinic z rodzaju Homeothrix (Thur.) Kirchn. - Two new species of the genus Homeothrix (Thur.) Kirchn. - Acta Hydrobiologica 2: 227-234.

Swofford, D.L. (2002): PAUP*. Phylogenetic Analysis Using Parsimony (*and Other Methods). Sinauer Associates, Sunderland, MA.

Taton, A., Brambilla, E., De Wit, R. \& Wilmotte, A. (2003): Cyanobacterial diversity in natural and artificial microbial mats of Lake Fryxell (McMurdo Dry Valleys, Antarctica): a morphological and molecular approach. - Appl. Environ. Microb. 69: 5137-5169.

Turner, S. (1997): Molecular systematics of the oxygenic photosynthetic bacteria. - Plant Syst. Evol. [Suppl.] 11: 13-52.

Voronichin, N.N. (1923): Novye vidy vodoroslej iz Kavkaza II. - Botanicheskie Materialy 2: 113128. [In Russian]

VorOnichin, N.N.(1932): K poznanyu flory i rastitelnosti vodoroslej presnych vodoemov Kryma, Tom 17. - Journal Botanique de l'USSR 3: 265-325. [In Russian]

West, W. \& West, G.S. (1897): Welwitsch's African freshwater algae. - J. Bot. 35: 235-243.

Wilgenbusch, J.C., Warren, D.L. \& Swofford, D.L. (2004): AWTY: A system for graphical exploration of MCMC convergence in Bayesian phylogenetic inference. - http://ceb.csit.fsu. edu/awty

Wilmotte, A. \& Herdman, M. (2001): Phylogenetic relationships among the cyanobacteria based on 16S rRNA sequences. - In: Boone, D.R. \&
Castenholz, R.W. (eds): Bergey's Manual of Systematic Bacteriology, $2^{\text {nd }}$ ed., vol. 1. - pp. 487-493, Springer, New York.

Wilmotte, A., Stam, W.T. \& Demoulin, V. (1997): Taxonomic study of marine oscillatoriacean strains (Cyanophyceae, Cyanobacteria) with narrow trichomes. III. DNA-DNA hybridization studies and taxonomic conclusions. - Arch. Hydrobiol./Algological Studies 87: 1-18.

ZwICKL, D.J. (2006): Genetic algorithm approaches for the phylogenetic analysis of large biological sequence datasets under the maximum likelihood criterion. - Ph.D. dissertation, The University of Texas at Austin.

(C) Czech Phycological Society (2011)

Recieved Sept 2010

Accepted Dec 2010 